\title{
Necrotizing pancreatitis presenting with hepatic portal venous gas and pneumatosis intestinalis
}

\author{
Elda Salazar, Fernando Escoto, Lisandro Salazar
}

\section{CASE REPORT}

A 68-year-old male with past medical history of diabetes mellitus and two previous episodes of mild acute pancreatitis was admitted to the hospital with a 12-hour history of severe epigastric pain and nausea. He reported no recent alcohol consumption, and current medication was metformin. On initial physical examination, he had a temperature of $38.5^{\circ} \mathrm{C}$, a heart rate of 94 beats per minute, and a respiratory rate of 26 breaths per minute. The patient had moderate epigastric abdominal tenderness without peritoneal irritation. Laboratory examination revealed white blood cell count $16,100 / \mathrm{mm}^{3}$, hematocrit $46.40 \%$, glucose $26.9 \mathrm{mmol} / \mathrm{L}$, serum amylase $1564 \mathrm{U} / \mathrm{L}$, serum lipase $4116 \mathrm{U} / \mathrm{L}$, serum alanine aminotransferase $380 \mathrm{U} / \mathrm{L}$, serum lactate dehydrogenase $421 \mathrm{U} / \mathrm{L}$, alkaline phosphatase $248 \mathrm{U} / \mathrm{L}$, direct bilirubin $3.0 \mathrm{mg} / \mathrm{dL}, \mathrm{BUN}$ $12 \mathrm{mg} / \mathrm{dL}$. Calcium, triglyceride, and electrolyte values were normal. Electrocardiography (ECG) and chest X-ray were normal. He was treated with intravenous fluids and pain relief medication. Several hours after admission the patient deteriorated, became hypotensive and dyspneic with increasing epigastric pain and peritoneal irritation, and required mechanical ventilation. Contrast-enhanced computed tomography of abdomen revealed gas in the portal vein, gastric pneumatosis, necrosis of the pancreas and pneumatosis intestinalis (Panels A and B).

Elda Salazar ${ }^{1}$, Fernando Escoto ${ }^{2}$, Lisandro Salazar ${ }^{3}$

Affiliations: ${ }^{1} \mathrm{MD}$, Chiefresident, Internal Medicine Hospital General San Juan de Dios, Guatemala, Guatemala; ${ }^{2} \mathrm{MD}$, ChiefResident, General Surgery. Hospital General San Juan de Dios, Guatemala, Guatemala; ${ }^{3}$ Gastroenterologist Hospital Centro Medico, Guatemala, Guatemala.

Corresponding Author: Elda Massiel Salazar, Hospital General San Juan de Dios, Guatemala City, Guatemala; Ph: 50257526464; Email: massiels24@gmail.com

Received: 26 August 2014

Accepted: 06 September 2014

Published: 07 October 2014
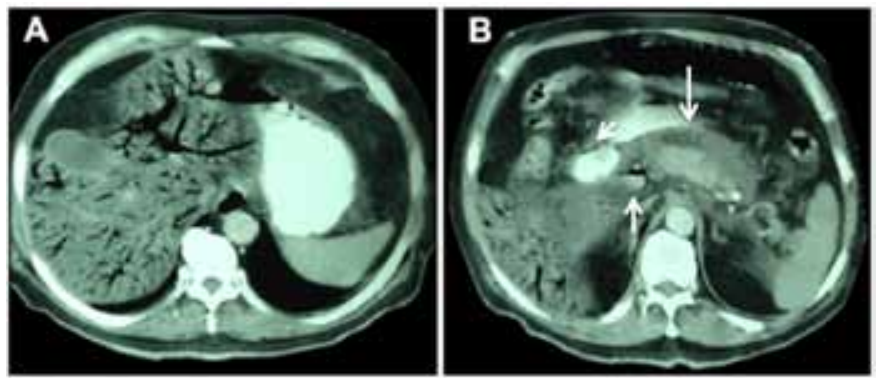

Figure 1: Diffuse gas in the portal vein and gastric pneumatosis (A) and (B arrows) necrosis of the pancreas and pneumatosis intestinalis. No biliary abnormality was identified.

The patient had acute necrotizing pancreatitis associated with hepatic portal venous gas and gastrointestinal pneumatosis. Despite aggressive resuscitation with fluids and broad spectrum antibiotics patient had an unrelenting, downhill course. Due to hemodynamic instability surgery could not be performed and patient died shortly thereafter.

\section{DISCUSSION}

Hepatic portal venous gas (HPVG) was described more than 55 years ago and is commonly associated with intramural bowel gas called pneumatosis intestinalis [1]. The frequency of detection of HPVG and pneumatosis intestinalis appears to be increasing. This increase may be the result of increased CT use. While the pathogenesis of HPVG is still unclear, and not yet well defined, various factors associated with it include bowel distention with mucosal damage, sepsis and gas embolization $[2,3]$. Mechanisms proposed indicate that the gas enters the portal circulation through the veins or lymphatics of the intestinal wall reaching the hepatic veins through the hepatic sinusoids. $[2,4]$. The overall mortality rate

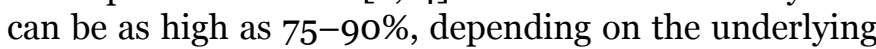
etiology $[1,5]$. In last decades, mortality rate seems to be lower, and is considered to be the result of early diagnosis as well as its association with unimportant causes, in which conservative management is more beneficial [6]. 
The presence of certain clinical features in pneumatosis intestinalis may help to predict the necessity of surgical exploration. It has been reported that history and physical examination suggestive of an acute abdominal process, arterial $\mathrm{pH}<7.3, \mathrm{HCO}_{3}<20 \mathrm{mmol} / \mathrm{L}$, an elevated lactate level, an elevated serum amylase level, or the presence of portal venous gas are indicatives of the need of direct surgical intervention [7-9]. There are no specific clinical features described in HPVG to determine the treatment strategy and outcome. The patient, reported in this study, had a severe acute necrotizing pancreatitis (BISAP score of 3 points and modified Glasgow score of 6 points) and had an unrelenting, downhill course and died shortly thereafter. Algorithms to guide the management of patients with HPVG have been proposed [10]. The finding of HPVG alone cannot be an indication of urgent surgery but the presence of HPVG on plain X-ray, clinical or radiological signs of intestinal necrosis predicts a high mortality $75-85 \%$ and warrants urgent treatment. [6, 11, 12]. For patients without peritonitis mortality approaches 20-30\% conservative management works well but clinicians are advised to have a low threshold for surgery and close monitoring of the patient [4, 13-14]. However, there is limited data to determine the best treatment choice.

\section{CONCLUSION}

This case highlights a rare and potentially ominous complication of acute necrotizing pancreatitis.

How to cite this article

Salazar E, Escoto F, Salazar L. Necrotizing pancreatitis presenting with hepatic portal venous gas and pneumatosis intestinalis. Int $\mathrm{J}$ Hepatobiliary Pancreat Dis 2014;4:45-47.

\section{Article ID: 100020IJHPDES2014}

$* * * * * * * * *$

doi:10.5348/ijhpd-2014-20-CL-8

$* * * * * * * * *$

\section{Author Contributions}

Elda Salazar-Substantial contributions to conception and design, Acquisition of data, Analysis and interpretation of data, Drafting the article, Revising it critically for important intellectual content, Final approval of the version to be published

Fernando Escoto - Acquisition of data, Analysis and interpretation of data. Revising it critically for important intellectual content. Drafting the article. Final approval of the version to be published

Lisandro Salazar - Acquisition of data, Analysis and interpretation of data. Revising it critically for important intellectual content. Drafting the article. Final approval of the version to be published

\section{Guarantor}

The corresponding author is the guarantor of submission.

\section{Conflict of Interest}

Authors declare no conflict of interest.

\section{Copyright}

(C) 2014 Elda Salazar et al. This article is distributed under the terms of Creative Commons Attribution License which permits unrestricted use, distribution and reproduction in any medium provided the original author(s) and original publisher are properly credited. Please see the copyright policy on the journal website for more information.

\section{REFERENCES}

1. Allaparthi SB, Anand CP. Acute gastric dilatation: A transient cause of hepatic portal venous gascase report and review of the literature. Case Rep Gastrointest Med. 2013;2013:723160.

2. Wolfe JN, Evans WA. Gas in the portal veins of the liver in infants. A roentgenographic demonstration with post-mortem anatomical correlation. Am J Roentgenol Radium Ther Nucl Med 1955 Sep;74(3):486-8.

3. Liebman PR, Patten MT, Manny J, Benfield JR, Hechtman HB. Hepatic--portal venous gas in adults: Etiology, pathophysiology and clinical significance. Ann Surg 1978 Mar;187(3):281-7.

4. Kesarwani V, Ghelani DR, Reece G. Hepatic portal venous gas: A case report and review of literature. Indian J Crit Care Med 2009 Apr-Jun;13(2):99-102.

5. Knechtle SJ, Davidoff AM, Rice RP. Pneumatosis intestinalis: Surgical management and clinical outcome. Ann Surg 1990 Aug;212(2):160-5.

6. Heng Y, Schuffler MD, Haggitt RC, Rohrmann CA. Pneumatosis intestinalis: A review. Am J Gastroenterol 1995 Oct;90(10):1747-58.

7. Hoover EL, Cole GD, Mitchell LS, Adams CZ Jr, Hassett J. Avoiding laparotomy in nonsurgical pneumoperitoneum. Am J Surg 1992 Aug;164(2):99103.

8. Galandiuk S, Fazio VW. Pneumatosis cystoides intestinalis: A review of the literature. Dis Colon Rectum 1986 May;29(5):358-63.

9. Keene JG. Pneumatosis cystoides intestinalis and intramural intestinal gas. J Emerg Med 1989 NovDec;7(6):645-50.

10. Naguib N, Gupta V, Mekhail P, Izzidien A, Masoud A. Careful approach to the ABCs of the management of portal venous gas. Arch Surg 2010 Jan;145(1):103-4. 
11. Yip CK, Ng VK, Man DW, Metreweli C. Sonographic recognition of pneumatosis intestinalis and portal gas in an 11-month-old infant - Case report. Australas Radiol 1990 May;34(2):169-71.

12. Chevallier P, Peten E, Souci J, Chau Y, Padovani $\mathrm{B}$, Bruneton JN. Detection of portal venous gas on sonography, but not on CT. Eur Radiol 2002 May;12(5):1175-8.
13. Martin-Smith JD, Larkin JO, Hogan JG, Ravi N, Reynolds JV. Necrotizing pancreatitis presenting with pneumatosis coli and hepatic portal venous gas. ANZ J Surg 2011 Jun;81(6):467-8.

14. Hou SK, Chern CH, How CK, Chen JD, Wang LM, Lee $\mathrm{CH}$. Hepatic portal venous gas: Clinical significance of computed tomography findings. Am J Emerg Med 2004 May;22(3):214-8.

\section{ABOUT THE AUTHORS}

Article citation: Salazar E, Escoto F, Salazar L. Necrotizing pancreatitis presenting with hepatic portal venous gas and pneumatosis intestinalis. Int J Hepatobiliary Pancreat Dis 2014;4:45-47.

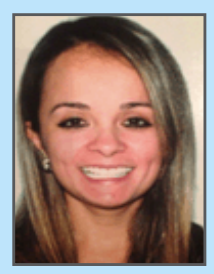

Elda Salazar is Chief Resident of the Department of Internal Medicine, Hospital General San Juan De Dios. Universidad De San Carlos, Guatemala city, Guatemala. She earned the undergraduate degree Medical Doctor from Universidad Francisco Marroquin, Guatemala city, Guatemala. Her research interests include disease of the pancreas and liver.

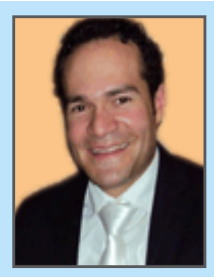

Fernando Escoto is Attending General Surgeon at Hospital General De Accidentes. Instituto Guatemalteco De Seguridad Social, Guatemala city, Guatemala. He earned his medical degree from Universidad De San Carlos, Guatemala and postgraduate degree Master in Science in General Surgery from Hospital General San Juan De Dios, Universidad De San Carlos, Guatemala. His research interests include gastrointestinal and trauma surgery.

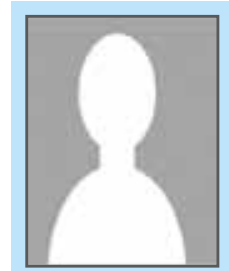

Lisandro Salazar is Interventional Gastroenterologist at Hospital Centro Medico, Guatemala city, Guatemala. He earned his medical degree and internal medicine degree from Universidad De San Carlos, Guatemala city, Guatemala and his Gastroenterology degree form Instituto Nacional De Ciencias Medicas Y Nutricion Salvador Zubiran, Mexico, Distrito Federal. His research interests include disease of the pancreas, bile duct and liver.

Access full text article on other devices

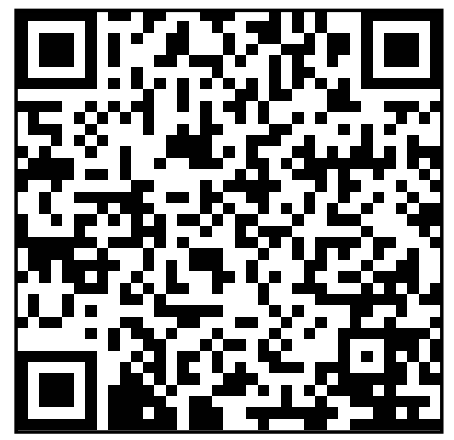

Access PDF of article on other devices

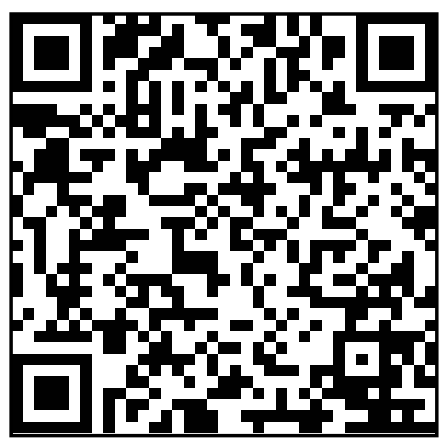

